\title{
MORPHOLOGICAL AND PHYSIOLOGICAL PARAMETERS IN YOUNG PLANTS OF Cordia trichotoma SUBMITTED TO THE APPLICATION OF PHOSPHORUS IN THE SOIL
}

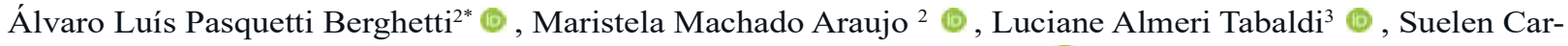

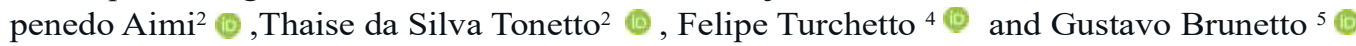 \\ ${ }^{1}$ Received on 06.10.2019 accepted for publication on 11.12.2019. \\ ${ }^{2}$ Universidade Federal de Santa Maria, Departamento de Ciências Florestais, Santa Maria, RS - Brasil. E-mail: <alvaro.berghetti@gmail. \\ com>, <araujo.maristela@gmail.com>, <suaimi@gmail.com>and <thaisetonetto@hotmail.com>. \\ ${ }_{3}^{3}$ Universidade Federal de Santa Maria, Departamento de Biologia, Santa Maria, RS - Brasil. E-mail: <lutabaldi@yahoo.com.br>. \\ ${ }^{4}$ Universidade Federal de Santa Maria, Departamento de Engenharia Florestal, Frederico Westphalen, RS - Brasil. E-mail: <turchetto. \\ felipe@gmail.com>. \\ ${ }^{5}$ Universidade Federal de Santa Maria, Departamento de Solos, Santa Maria, RS - Brasil. E-mail: <brunetto.gustavo@gmail.com>. \\ *Corresponding author.
}

\begin{abstract}
The application of phosphorus (P) doses in the soil can increase the growth of native tree species of economic and environmental interest, such as Cordia trichotoma. Thus, this research aims to evaluate the morphological and the physiological parameters in C. trichotoma seedlings, cultivated in soil with increased $\mathrm{P}$ content. The experiment was conducted under greenhouse conditions in pots with $2.5 \mathrm{dm}^{-3}$ of soil, four doses of $\mathrm{P}\left(0,150,300\right.$ and $\left.450 \mathrm{mg} \mathrm{dm}^{-3}\right)$, and six replicates. $\mathrm{P}$ content in the soil, $\mathrm{P}$ concentrations in the leaves, morphological attributes (height, stem diameter, aerial dry matter, root dry matter, and leaf area) and physiological attributes (photosynthetic pigment content and chlorophyll $\alpha$ fluorescence) were determined 180 days after transplantation. The increase in the available P content in the soil allowed greater absorption of this element by the plant's roots, increasing the concentration in the leaves, and therefore favoring the energetic metabolism of the plants. In addition, the higher influx and accumulation of $\mathrm{P}$ in the plant when $450 \mathrm{mg}$ $\mathrm{dm}^{-3}$ was used, increased the concentration of the photosynthetic pigments and increased the photosynthetic capacity of the C. trichotoma seedlings. The highest use of the light energy by photosystem II $\left(\mathrm{F}_{\mathrm{v}} / \mathrm{F}_{\mathrm{m}}=0.76\right)$ was observed in the seedlings cultivated with $450 \mathrm{mg} \mathrm{dm}^{-3}$ of $\mathrm{P}$, with a $95 \%$ increase when compared to seedlings without $\mathrm{P}$. Thus, we observed that this tree species is demanding and responsive to the higher $\mathrm{P}$ content available in the soil.
\end{abstract}

Keywords: Chlorophyll a fluorescence; Louro-pardo; Phosphate fertilizer.

\section{PARAMMTROS MORFOLÓGICOS E FISIOLÓGICOS EM PLANTAS JOVENS DE Cordia trichotoma SUBMETIDAS A APLICAÇÃO DE FÓSFORO NO SOLO}

\begin{abstract}
RESUMO - A aplicação de doses de fósforo (P) no solo pode aumentar o crescimento de espécies arbóreas nativas de interesse econômico e ambiental, como a Cordia trichotoma. Assim, esta pesquisa tem por objetivo avaliar parâmetros morfológicos e fisiológicos em mudas de $\boldsymbol{C}$. trichotoma cultivadas em solo com aumento do teor de P. O experimento foi conduzido em casa de vegetação, em vasos com $2,5 \mathrm{dm}^{-3}$ de solo, com quatro doses de $\mathrm{P}$ $\left(0,150,300\right.$ e $\left.450 \mathrm{mg} \mathrm{dm}^{-3}\right)$ e seis repetições. O teor de $\mathrm{P}$ no solo, as concentrações de $\mathrm{P}$ nas folhas, os atributos morfológicos (altura, diâmetro do coleto, matéria seca aérea, matéria seca radicular e área foliar) e os atributos fisiológicos (teor de pigmentos fotossintéticos e fluorescência da clorofila a) foram determinados aos 180 dias após o transplante. O incremento no teor de $\mathrm{P}$ disponível no solo permitiu maior absorção desse elemento pelas raízes das plantas, elevando a concentração nas folhas. Isso favoreceu o metabolismo energético das plantas, proporcionando maior crescimento. Além disso, o maior influxo e acúmulo de $\mathrm{P}$ na planta quando utilizado 450 $\mathrm{mg} \mathrm{dm}{ }^{-3}$, incrementou a concentração dos pigmentos fotossintéticos e elevou a capacidade fotossintética das
\end{abstract}


mudas de $\boldsymbol{C}$. trichotoma. O maior aproveitamento da energia luminosa pelo fotossistema $\mathrm{II}\left(\mathrm{F}_{\mathrm{v}} / \mathrm{F}_{\mathrm{m}}=0,76\right)$ foi observado nas mudas cultivadas com $450 \mathrm{mg} \mathrm{dm}^{-3} \mathrm{de} \mathrm{P}$, com aumento de $95 \%$ quando comparadas às mudas sem adição de P. Assim, percebemos que essa espécie arbórea, é exigente e responsiva em relação ao maior teor de P disponível no solo.

Palavras-Chave: Fluorescência da clorofila a; Louro-pardo; Adubação fosfatada.

\section{INTRODUCTION}

The species Cordia trichotoma (Vell.) Arrab. ex Steud. (louro-pardo) belonging to the Boraginaceae family is widely distributed in tropical and subtropical forests in Argentina, Bolivia, Brazil, Paraguay and Uruguay. This species is fast growing and presents wood with high economic value added, due to its quality, workability and good finish, being much used for luxury furniture and decorative coating (Berghetti et al., 2016; Cadorin et al., 2015; Coradin et al., 2011). Thus, C. trichotoma has the potential to be cultivated in the formation of commercial forest stands (Rossi and Sartoretto, 2014). However, the literature does not provide important information for planting, such as the adequate use of fertilizers, especially phosphates, since the majority of soils destined to forest plantations in Brazil have low availability of phosphorus (P) (Gonçalves et al., 2008a; Gonçalves et al., 2008b), because of their high adsorption affinity to functional groups of reactive particles such as $\mathrm{Fe}$ and $\mathrm{Al}$ oxides and hydroxides (Bortoluzzi et al., 2015; Fink et al., 2016).

In forestry, liming and the application of phosphate fertilizers are practices used to raise the $\mathrm{P}$ content available in the soil (Gonçalves et al., 2008a; Gonçalves et al., 2008b). As a result, part of the nutrient can approach the external surface of the roots and can be absorbed from the soil solution in the form of inorganic phosphate, raising its concentration in the organs of the plants (Brunetto et al., 2015). In the interior of the plants, including the woody ones, the concentration of $\mathrm{P}$ determines the growth and the photosynthetic activity (Warren, 2011). Plants grown in soils with higher application of phosphate fertilizers and, consequently, higher availability of $\mathrm{P}$, tend to accumulate higher levels of P in the leaves (Lambers et al., 2011; Piccin et al., $2017 \mathrm{~b}$ ) and increase growth in height, diameter, leaf area and dry matter production (Crous et al., 2015; Tng et al., 2014; Zhou et al., 2017).
The productivity of plants depends mainly on photosynthesis. Plants that are deficient in $\mathrm{P}$ present a reduction in ADP-ATP biosynthesis, in the carboxylation/ regeneration of ribulose-1.5-biphosphate (RuBP) and in the rubisco activity, as well as a lower stomatal conductance and $\mathrm{CO}_{2}$ concentration in the substomatal chambers (Hidaka and Kitayama, 2013; Thomas et al., 2006; Warren, 2011). The damage of the photochemical reactions in the leaves can be detected by the chlorophyll $\alpha$ fluorescence analysis, so that when there are nutritional limitations that cause stress, there is an increase in the values of initial and maximum fluorescence and reduction in the maximum quantum yield of photosystem II (Banks, 2017; Schansker et al., 2014).

Information on the responses of $\mathrm{P}$ fertilization and nutrient utilization in $C$. trichotoma plants grown in subtropical regions must be explored. Thus, this study aimed to evaluate morphological and physiological parameters in C. trichotoma seedlings cultivated in soil with increased $\mathrm{P}$ content.

\section{MATERIALS AND METHODS}

\subsection{Experiment location, collection and preparation of the seeds and soil}

The study was carried out from November to June in the greenhouse of the Department of Forest Sciences of the Federal University of Santa Maria (UFSM), Santa Maria, state of Rio Grande do Sul, Southern Brazil (29 $43^{\circ} 15^{\prime \prime} \mathrm{S}$ and 53 $43^{\prime} 18^{\prime}$ ' O). Seeds of C. trichotoma were obtained from diaspores collected in fragments of Deciduous Seasonal Forest (29 $45^{\prime} 22^{\prime \prime} \mathrm{S}$ and 53'34'47", O). After the collection, the diaspores were processed as suggested by Berghetti et al. (2015). The seeds were sown in vermiculite and packed in polypropylene trays. The trays were laid out on benches in a greenhouse. The averages of temperature and relative humidity were $25.7^{\circ} \mathrm{C}$ and $82 \%$, respectively. Irrigations were performed four times a day, for three minutes, using microsprinklers, with a flow rate of $169 \mathrm{~L} \mathrm{~h}^{-1}$.

Revista Árvore 2020;44:e4404 
At 50 days after sowing, seedlings with developed cotyledons and protophylls were transplanted into polypropylene pots containing $2.5 \mathrm{dm}^{-3}$ of a Sandy Typic Hapludalf soil (Ditzler and Monger, 2017). The soil was collected in the 0.0-0.20 m layer, air dried and sieved with a $2 \mathrm{~mm}$ mesh. In this soil, no acidity neutralization was necessary (Table 1), because the exchangeable $\mathrm{Ca}$ and $\mathrm{Mg}$ contents were 2.7 and $1.2 \mathrm{cmolc} \mathrm{dm}^{-3}$, respectively, which is considered adequate for native forest species (Bellote and Neves, 2001).

\subsection{Experimental design and treatments}

The experimental design was completely randomized, with six replicates. The treatments consisted of four concentrations of $\mathrm{P}_{2} \mathrm{O}_{5}, 0$ (control), 150, 300 and $450 \mathrm{mg}$ P2O5 dm $\mathrm{dm}^{-3}$ of soil. The concentrations of P2O5 (source: diphosphorus pentoxide), $100 \mathrm{mg} \mathrm{N} \mathrm{dm}^{-3}$ of soil (source: ammonium nitrate) and $50 \mathrm{mg} \mathrm{K} \mathrm{dm}^{-3}$ of soil (source: potassium chloride) were applied to the soil followed by immediate homogenization. The soil was packed in polypropylene pots with a capacity of $3 \mathrm{~L}$. Distilled water was added in each pot to raise the field capacity to $60 \%$. The pots were weighed daily and, when necessary, distilled water was added to maintain the soil at its field capacity, adding distilled water when soil humidity reduced $40 \%$ of that level. During the experiment a seedling of $C$. trichotoma was kept in each pot, the average temperature inside the greenhouse was $27.4^{\circ} \mathrm{C}$ and the average relative humidity was $79 \%$.

\subsection{Morphological attributes and nutrient analysis in tissue and soil}

At 180 days after transplantation (DAT), the plant height was measured with a millimeter ruler and the stem diameter with a digital caliper (accuracy of $0.01 \mathrm{~mm}$ ). The aerial part of the plant was cut close to the soil surface and divided into leaves and stem. The roots were manually separated from the soil and then washed with running water. The collected leaves were distributed on white paper with millimeter scale, pressed with transparent glass plate and photographed with a digital camera with 1.4 zoom (SONY Cyber-shot, 8.1 megapixels). Afterwards, the images were treated (contrast and brightness adjustment) and processed for determination of the leaf area (LF), with the aid of Image $\mathrm{J}$. The aerial part (leaves and stem) and the roots were dried in an air circulation oven forced to $70^{\circ} \mathrm{C}$ until constant weight, for the determination of the dry matter.

The leaves were ground in a Willey mill, sieved with a $2 \mathrm{~mm}$ mesh and then subjected to nitroperchloric digestion (Tedesco et al., 1995). In the extract, P was analyzed in a spectrophotometer (model SF325NM - Bel Engineering, Italy) (Tedesco et al., 1995). In addition, a soil sample was collected in each pot after cultivation. The soil was air dried, sieved with a $2 \mathrm{~mm}$ mesh and subjected to $\mathrm{P}$ extraction by the Mehlich-1 extractor $\left(0.05 \mathrm{~mol} \mathrm{~L}^{-1} \mathrm{HCl}+0.0125 \mathrm{~mol} \mathrm{~L}^{-1} \mathrm{H}_{2} \mathrm{SO}_{4}\right)$. $\mathrm{P}$ was determined in a spectrophotometer (model SF325NM Bel Engineering, Italy).

In addition, the agronomic efficiency [(dry weight of shoots with $\mathrm{P}$ - dry weight of shoots without $\mathrm{P}$ )/amount of $\mathrm{P}$ applied] was determined according to Fageria et al. (2003) in each experimental unit.

\subsection{Assessment of photosynthetic pigments}

For the analysis of photosynthetic pigments, fully expanded leaves of six replications per treatment were collected and frozen in liquid N2 at 180 days

Table 1 - Physical and chemical attributes of the soil of the 0.0-0.20 m layer grown with Cordia trichotoma seedlings.

Tabela 1 - Atributos físicos e químicos do solo da camada 0.0-0.20 m cultivado com mudas de Cordia trichotoma.

\begin{tabular}{lc}
\hline Attributes & Values \\
\hline Clay (pipette method) $\left(\mathrm{g} \mathrm{kg}^{-1}\right)$ & 350 \\
Sand(pipette method) $\left(\mathrm{g} \mathrm{kg}^{-1}\right)$ & 480 \\
Silt(pipette method) $\left(\mathrm{g} \mathrm{kg}^{-1}\right)$ & 170 \\
Organic matter $\left(\right.$ Walkley-Black method) $\left(\mathrm{g} \mathrm{kg}^{-1}\right)$ & 25 \\
Base saturation $\left(\mathrm{g} \mathrm{kg}^{-1}\right)$ & 157 \\
pH in water $(1: 1)$ & 4.6 \\
Available P $($ extracted by Mehlich & \\
Available $\mathrm{K}\left(\right.$ extracted by Mehlich $\left(\mathrm{mg} \mathrm{dm}^{-3}\right)\left(\mathrm{mg} \mathrm{dm}^{-3}\right)$ & 0.7 \\
Exchangeable Ca(extracted by KCl $\left.1 \mathrm{~mol} \mathrm{~L}^{-1}\right)\left(\mathrm{cmolcdm}^{-3}\right)$ & 32 \\
Exchangeable Mg $\left(\right.$ extracted by KCl $\left.1 \mathrm{~mol} \mathrm{~L}^{-1}\right)\left(\mathrm{cmolcdm}^{-3}\right)$ & 2.7 \\
Exchangeable Al(extracted by KCl $\left.1 \mathrm{~mol} \mathrm{~L}^{-1}\right)\left(\mathrm{cmolcdm}^{-3}\right)$ & 1.2 \\
Cation exchange capacity at pH $7.0 .\left(\mathrm{cmolcdm}^{-3}\right)$ & 5.7 \\
\hline
\end{tabular}


(DAT). Chlorophyll $\alpha(C h l \alpha)$, chlorophyll $b(\mathrm{Chl} b)$ and carotenoids content were analyzed according to the methodology described by Hiscox and Israelstam (1979), where $0.05 \mathrm{~g}$ of a fresh leaf sample were incubated at $65^{\circ} \mathrm{C}$ with dimethylsulfoxide (DMSO) for two hours. The concentrations of pigments were obtained after reading the absorbance in a spectrophotometer (model SF325NM - Bel Engineering, Italy), at 480, 645 and $663 \mathrm{~nm}$, according to the methodology proposed by Lichtenthaler (1987).

\subsection{Assessment of chlorophyll a fluorescence}

The emission of chlorophyll $\alpha$ fluorescence was analyzed in leaves at 180 DAT, using a JUNIOR-PAM portable light-modulated fluorometer(Walz, Germany). Measurements were performed in the morning (8:0011:00 h), using the first fully expanded leaf (Souza et al., 2013), in three plants per treatment. Previously, the leaf was adapted to the dark for 30 minutes, for measurement of the initial fluorescence $\left(\mathrm{F}_{\mathrm{o}}\right)$. Then the sample was subjected to a pulse of saturating light (10000 umol m $\mathrm{m}^{-2} \mathrm{~s}^{-1}$ ) for $0.6 \mathrm{~s}$ to evaluate the maximum fluorescence $\left(\mathrm{F}_{\mathrm{m}}\right)$, while the maximum quantum yield of PSII $\left(\mathrm{F}_{\mathrm{v}} / \mathrm{F}_{\mathrm{m}}\right)$ was evaluated using the fluorescence induction curve.

\subsection{Statistical analysis}

The results were tested for normality assumptions of residues and the homogeneity of variance by the Shapiro-Wilk and Bartlett test, respectively. After that, analysis of variance (ANOVA) was performed according to the model: $\mathrm{Y}_{\mathrm{ij}}=\mathrm{m}+\mathrm{t}_{\mathrm{i}}+\delta \mathrm{ij}$, where: $\mathrm{Y}_{\mathrm{ij}}$ is the value observed; $m$ corresponds to the population mean; $t_{i}$ is the effect of the treatment and $\delta i j$ is the effect of the random error occurring in each experimental unit. When there was a significant effect, the means were adjusted using polynomial regressions $(p \leq 0.05)$, or compared by the Tukey test $(p \leq 0.05)$ using the statistical package SISVAR (Ferreira, 2014).

\section{RESULTS}

\section{1 $P$ in soil and tissue, and morphological parameters}

The P contents in the soil extracted by Mehlich-1 increased in a linear way with the increase of the doses of $\mathrm{P}_{2} \mathrm{O}_{5}$ in the soil ( $p=0.0001$ ) (Figure 1a). In the soil, with the application of $450 \mathrm{mg} \mathrm{P}_{2} \mathrm{O}_{5} \mathrm{dm}^{-3}$ the availability of $\mathrm{P}$ was about 92 times higher than the content observed in the control soil (Figure 1a).

The $\mathrm{P}$ concentrations in the leaves increased in a quadratic manner $(p=0.0174)$ with the increase of the availability of this nutrient in the soil. The leaves of the plants cultivated in the soil with application of $450 \mathrm{mg} \mathrm{P}_{2} \mathrm{O}_{5} \mathrm{dm}^{-3}$ had $\mathrm{P}$ concentration $180 \%$ higher, in comparison to the leaves of the plants cultivated in the control soil (Figure 1b).

The values of height and stem diameter of the C. trichotoma seedlings increased linearly with the increased dose of $\mathrm{P}_{2} \mathrm{O}_{5}$ applied to the soil (Figure 2a and $2 b)$. The plants cultivated in the soil with application of $450 \mathrm{mg}_{2} \mathrm{O}_{5} \mathrm{dm}^{-3}$ presented the highest averages for height $(26.6 \mathrm{~cm})$ and stem diameter $(7.7 \mathrm{~mm})$. In this condition, the values observed for height and stem diameter were $239 \%$ and $220 \%$ higher than those observed in the plants grown in the control soil (Figure $2 a$ and $2 b$ ).

The aerial dry matter production increased linearly (Figure 2c) and the roots in a quadratic manner (Figure 2d) with the increase in the $\mathrm{P}_{2} \mathrm{O}_{5}$ concentration applied to the soil. The higher aerial dry matter production (11.6 g plant-1) was observed in the plants submitted to application of $450 \mathrm{mg} \mathrm{P}_{2} \mathrm{O}_{5} \mathrm{dm}^{-3}$ (Figure 2c), equivalent to an increase of $92 \%$ in relation to seedlings cultivated without fertilization. The root dry matter production in the plants cultivated in the soil with the application of $450 \mathrm{mg} \mathrm{P}_{2} \mathrm{O}_{5} \mathrm{dm}^{-3}\left(10.7 \mathrm{~g} \mathrm{plant}^{-1}\right)$ was 11 times higher than the values observed in the roots of the plants grown in the control soil.

The application of increasing doses of $\mathrm{P}_{2} \mathrm{O}_{5}$ in the soil did not alter the agronomic efficiency of $\mathrm{C}$. trichotoma seedlings. However, the highest values
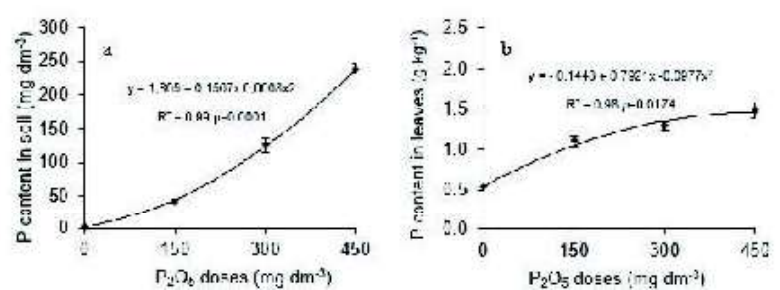

Figure 1 - $\mathrm{P}$ content in soil (a) and $\mathrm{P}$ concentration in leaves (b) of Cordia trichotoma seedlings submitted to the applications of doses of $\mathrm{P}_{2} \mathrm{O}_{5}$ and cultivated for 180 days

Figura 1 - Conteúdo de P no solo (a) e concentração de P em folhas (b) de mudas de Cordia trichotoma submetidas a aplicação de doses de $\mathrm{P}_{2} \mathrm{O}_{5}$ e cultivadas durante 180 dias. 

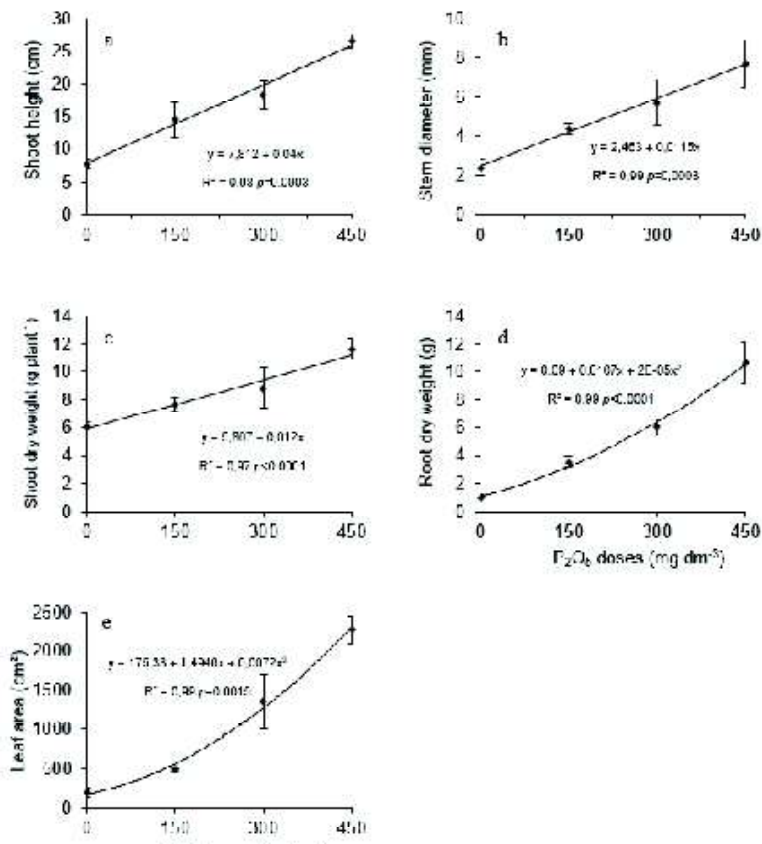

Figure 2 - Hêight (a), stem diameter (b), aerial dry matter (c) root dry matter (d) and leaf area (e), in Cordia trichotoma seedlings submitted to doses of $\mathrm{P}_{2} \mathrm{O}_{5}$ cultivated for 180 days.

Figura 2 - Altura (a), diâmetro do coleto (b), matéria seca da parte aérea (c) e de raizes (d) e área foliar (e), em mudas de Cordia trichotoma submetidas a aplicação de doses de $\mathrm{P}_{2} \mathrm{O}_{5}$, cultivadas durante 180 dias.

(28.35 $\left.\mathrm{kg} \mathrm{kg}^{-1}\right)$ were observed in plants cultivated with $450 \mathrm{dm}^{-3}$ de $\mathrm{P}_{2} \mathrm{O}_{5}$ (Table 2).

Leaf area values increased in a quadratic manner with the $\mathrm{P}_{2} \mathrm{O}_{5}$ dose (Figure 2e). The leaf area in the plants cultivated in the soil with $450 \mathrm{mg} \mathrm{P}_{2} \mathrm{O}_{5} \mathrm{dm}^{-3}$ was 11 times higher than that observed in the plants grown in the control soil.

\subsection{Assessment of photosynthetic pigments and chlorophyll a fluorescence}

The values of chlorophyll a $(C h l \alpha)$, chlorophyll $b$ $(\mathrm{Chl} b)$ and carotenoids increased in a quadratic manner with the increase in the concentration of $\mathrm{P}_{2} \mathrm{O}_{5}$ in the soil (Figure 3a, 3b, and 3c). Plants grown in soils with the addition of $450 \mathrm{mg} \mathrm{P}_{2} \mathrm{O}_{5} \mathrm{dm}^{-3}$ had the highest values of $C h l \alpha$, Chl $b$ and carotenoids. On the other hand, the lowest concentrations of these photosynthetic pigments were observed in the plants grown in the soil submitted to the application of $300 \mathrm{mg} \mathrm{P} \mathrm{dm}^{-3}$ (Figure $3 \mathrm{a}, 3 \mathrm{~b}$, and $3 c)$.
Table 2 - Agronomic efficiency of Cordia trichotoma seedlings submitted to the applications of doses of $\mathrm{P}_{2} \mathrm{O}_{5}$ and cultivated for 180 days.

Tabela 2 - Eficiência agronômica de mudas de Cordia trichotoma submetidos às aplicações de doses de $\mathrm{P}_{2} \mathrm{O}_{5}$ e cultivada por 180 dias.

\begin{tabular}{lc}
\hline $\begin{array}{l}\text { Doses of } \mathrm{P}_{2} \mathrm{O}_{5} \\
\left.(\mathrm{mg} \mathrm{dm})^{-3}\right)\end{array}$ & $\begin{array}{r}\text { Agronomic } \\
\text { efficiency } \\
\left(\mathrm{kg} \mathrm{kg}^{-1}\right)\end{array}$ \\
\hline 150 & $24.58 * \mathrm{~ns}$ \\
300 & 21.45 \\
450 & 28.35 \\
Means & 24.80 \\
$\mathrm{CV}(\%)$ & 37.16 \\
${ }^{*} \mathrm{~ns}=\mathrm{F}$ not significant at 5\% probability. CV= coefficient of variation. \\
$*$ ns = F não significativo a 5\% de probabilidade. CV = coeficiente de variação.
\end{tabular}

Chlorophyll fluorescence parameters of the $C$. trichotoma seedlings, initial fluorescence $\left(\mathrm{F}_{\mathrm{o}}\right)$ and maximum fluorescence $\left(\mathrm{F}_{\mathrm{m}}\right)$ decreased in a quadratic manner as the concentration of $\mathrm{P}_{2} \mathrm{O}_{5}$ in the soil increased (Figure $3 \mathrm{~d}$ and $3 \mathrm{e}$ ). The values of the maximum quantum yield $\left(\mathrm{F}_{\mathrm{v}} / \mathrm{F}_{\mathrm{m}}\right)$ of photosystem II (PSII) increased linearly with the increase in the concentration of $\mathrm{P}_{2} \mathrm{O}_{5}$ applied to the soil (Figure 3f). The lowest values of $F_{o}$ and $F_{m}$ were observed in the leaves of the plants cultivated in the soil with the application of $450 \mathrm{mg} \mathrm{P}_{2} \mathrm{O}_{5} \mathrm{dm}^{-3}$ (Figure $3 \mathrm{~d}$ and $3 \mathrm{e})$. The highest $\mathrm{F}_{\mathrm{v}} / \mathrm{F}_{\mathrm{m}}$ ratio $(0.76)$ was observed in seedlings cultivated in the soil with the application of $450 \mathrm{mg} \mathrm{P}_{2} \mathrm{O}_{5} \mathrm{dm}^{-3}$. This was an increase of $95 \%$ in relation to the seedlings cultivated without the addition of $\mathrm{P}_{2} \mathrm{O}_{5}$ (Figure 3f).

\section{DISCUSSION}

The highest values of the morphological parameters, height, stem diameter, aerial and root dry matter production observed in the plants cultivated in the soil with the application of $450 \mathrm{mg}_{2} \mathrm{O}_{5} \mathrm{dm}^{-3}$, are attributed to the higher P content in the soil (Figure 1a). In this condition, $\mathrm{P}$ was probably mainly absorbed in $\mathrm{H}_{2} \mathrm{PO}_{4}$ - and $\mathrm{HPO}_{4}^{2}$ - forms (Elanchezhian et al., 2015), and part of the nutrient was transported to the aerial part and accumulated in organs, as the leaves (Figure 1b), where its increase was observed, with the increase in the dose of $\mathrm{P}_{2} \mathrm{O}_{5}$ applied to the soil.

The $\mathrm{P}$ in the tissue stimulated plant energy metabolism, cell division and expansion (Marschner, 2012; Noack et al., 2014; Zhou et al., 2017), which reflected in the increase in the leaf area of the plants (Figure 2e). As a result of the increase in the leaf area, a higher light absorption, $\mathrm{CO}_{2}$ assimilation and, 

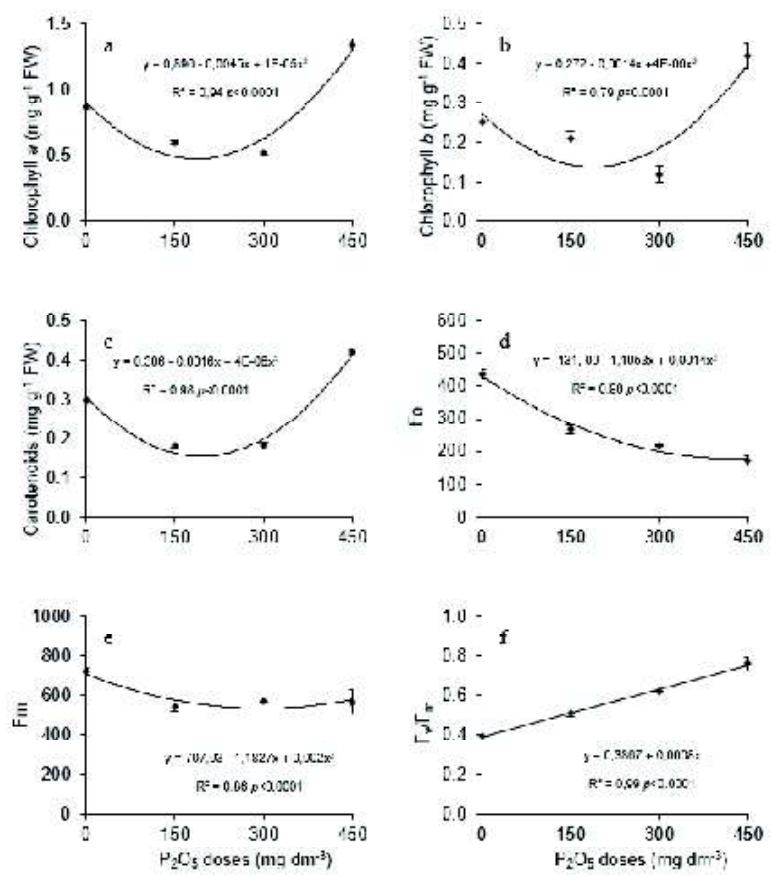

Figure 3 - Values of chlorophyll $\alpha$ (a), chlorophyll $b$ (b), carotenoids $(\mathrm{c})$, initial fluorescence $\left(\mathrm{F}_{\mathrm{o}}\right)(\mathrm{d})$, maximum fluorescence $\left(\mathrm{F}_{\mathrm{m}}\right)(\mathrm{e})$ and maximum quantum yield $\left(\mathrm{F}_{\mathrm{v}}\right.$ $\mathrm{F}$ ) in Cordia trichotoma seedlings submitted to doses of $\mathrm{P}_{2} \mathrm{O}_{5}$ and cultivated for 180 days

Figura 3 - Valores de clorofila a (a), clorofila $b(b)$, carotenoides (c), fluorescência inicial $(F)$ (d), fluorescência máxima $\left(F_{m}\right)(e)$ e rendimento quântico máximo $\left(F_{v} / F_{m}\right)(f)$, em mudas de Cordia trichotoma submetidas a aplicação de doses de $\mathrm{P}_{2} \mathrm{O}_{5}$ e cultivadas durante 180 dias.

consequently, higher photosynthetic rate occurs (Crous et al., 2015; Zambrosi et al., 2012a; Zambrosi et al., $2012 b$ ), due to the greater amount of light energy intercepted (Taiz and Zeiger, 2013).

The concentration of $\mathrm{P}$ in the leaves $\left(1.48 \mathrm{~g} \mathrm{~g} \mathrm{~kg}^{-1}\right)$ of the plants cultivated in the soil with $450 \mathrm{mg} \mathrm{P}_{2} \mathrm{O}_{5} \mathrm{dm}^{-3}$ was interpreted as high, being considered superior to the suggested ideal range for the genus Eucalyptus, which varies between 1.0 and $1.3 \mathrm{~g} \mathrm{~kg}^{-1}$ (Melo et al., 2016).

This is because plants grown in soils with high $\mathrm{P}$ content normally absorb amounts of $\mathrm{P}$ above their metabolic need, leading to higher $\mathrm{P}$ allocation in the cell vacuole (Lambers et al., 2011; Noack et al., 2014; Veneklaas et al., 2012). On the other hand, the concentration of $\mathrm{P}$ in the leaves of the plants cultivated in the control soil $\left(0.53 \mathrm{~g} \mathrm{~kg}^{-1}\right)$, can be interpreted as low (Melo et al., 2016), proving insufficient to provide to plant metabolism suitable conditions for satisfactory growth.
With the increase in the $\mathrm{P}$ content available in the soil, there is a greater supply of this element to the roots of the plants and probably greater absorption (Piccin et al., 2017a). A large part of the P absorbed is transported and accumulated in the leaves of the plants (Veneklaas et al., 2012), where it provides increased energy metabolism, increased cell division (Marschner, 2012), stomatal conductance (Warren, 2011) and, consequently, increased synthesis of photosynthetic pigments (Jiang et al., 2009). Increasing concentrations of chlorophyll $\alpha$ and $b$ and carotenoids in the leaves promotes greater absorption and capture of light in different regions of the spectrum in the early stages of the photosynthetic process (Taiz and Zeiger, 2013). Thus, a higher resonance energy transfer occurs from the antenna complexes to the reaction centers, where the energy can be used for the photochemical reactions responsible for biomass production (Taiz and Zeiger, 2013).

The lowest index of photochemical $\left(\mathrm{F}_{\mathrm{o}}=172.5\right)$ and dissipation $\left(\mathrm{F}_{\mathrm{m}}=565.5\right)$ energy losses of the PSII antenna complex observed in the seedlings cultivated in the soil with $450 \mathrm{mg} \mathrm{P}_{2} \mathrm{O}_{5} \mathrm{dm}^{-3}$ (Figure $3 \mathrm{~d}$ and $3 \mathrm{e}$ ), indicates that in this condition, the seedlings do not present damage in the reaction center of the PSII and have high excitation energy transfer from the light collecting system to the reaction center (Schansker et al., 2014; Stirbet and Govindjee, 2011).

This is in agreement with the data on the maximum quantum yield $\left(\mathrm{F}_{\mathrm{v}} / \mathrm{F}_{\mathrm{m}}\right)$ of the PSII (Figure 3f). The greater use $\left(\mathrm{F}_{\mathrm{v}} / \mathrm{F}_{\mathrm{m}}=0.76\right)$ of the light energy of PSII indicates that most of the light energy is being directed to the photochemical stage of photosynthesis, rather than being lost by fluorescence of chlorophyll $\alpha$ (Baker, 2008).

According to Araújo and Deminicis (2009), healthy plants should have an $\mathrm{F}_{\mathrm{v}} / \mathrm{F}_{\mathrm{m}}$ ratio between 0.75 and 0.85 . Thus, for $C$. trichotoma, the values close to 0.76 (Figure 3f) can be considered good predictors of growth, because under these conditions the seedlings showed higher growth and dry matter production. Similar results were observed by Turchetto et al. (2016) studying the performance of native tree species, including $C$. trichotoma, in nursery.

The reduction of $\mathrm{F}_{\mathrm{v}} / \mathrm{F}_{\mathrm{m}}$, observed in the seedlings grown in the control soil, characterizes a state of photoinhibition in the plants (Araújo and Deminicis, 2009), and because of this, a smaller amount of energy absorbed by the plant through the antenna complex is

Revista Árvore 2020;44:e4404 
used to reduce carbon and produce dry matter, which helps to explain the low dry matter production in this condition of low $\mathrm{P}$ availability in the soil (Tiecher et al., 2016).

In this study, the highest values of agronomic efficiency observed at the $450 \mathrm{mg} \mathrm{dm}^{-3}$ dose of $\mathrm{P}_{2} \mathrm{O}_{5}$ occurred mainly because of the larger leaf area and aerial dry matter production of Cordia trichotoma seedlings (Figure 1). A similar behavior was also observed by Magalhães et al. (2017) in Eucalyptus urograndis seedlings where the highest agronomic efficiency values occurred in the higher doses of different phosphate fertilizers.

Besides that, the addition of $\mathrm{P}_{2} \mathrm{O}_{5}$ in the soil increased the availability of $\mathrm{P}$ yielding $C$. trichotoma seedlings with higher internal concentration of $\mathrm{P}$. Thus, the plants cultivated at the concentration of $450 \mathrm{mg}$ $\mathrm{P}_{2} \mathrm{O}_{5} \mathrm{dm}^{-3}$ of soil showed the highest values for the morphological parameters height, stem diameter, aerial and root dry matter. This is consistent with the results observed by authors who studied the effects of different P levels on different forest species (Wu et al., 2011; Yang et al., 2014; Yao et al., 2011).

In addition, the photosynthetic pigments and the chlorophyll a emission also presented the best values in the plants cultivated in the soil with higher P availability.

Thus, it is believed that although $C$. trichotoma plants tolerate low levels of $\mathrm{P}$ in the soil, they are able to respond positively to phosphate fertilization with higher growth and dry matter production.

\section{CONCLUSIONS}

The seedlings of Cordia trichotoma proved to be responsive to the increase in the $\mathrm{P}$ content available in the soil. The application of the highest concentration of $\mathrm{P}\left(450 \mathrm{mg} \mathrm{P}_{2} \mathrm{O}_{5} \mathrm{dm}^{-3}\right.$ ) stimulates higher growth in height, stem diameter, aerial and root dry matter and leaf area. The seedlings grown in the soil with $450 \mathrm{mg} \mathrm{P}_{2} \mathrm{O}_{5} \mathrm{dm}^{-3}$ presented the highest levels of photosynthetic pigments, greater use of light energy by PSII and lower rate of energy loss due to fluorescence.

\section{ACKNOWLEDGMENTS}

We are grateful to Conselho Nacional de Desenvolvimento Científico e Tecnológico (Brazilian National Council for Scientific and Technological
Development) - CNPq and the Coordenação de Aperfeiçoamento de Pessoal de Nível Superior (Coordination for the Improvement of Education Personnel Higher Level Personnel) - Capes for the scholarships provided and the financial resources made available for this study.

\section{REFERENCES}

Araújo SAC, Deminicis BB. Fotoinibição da Fotossíntese. Revista Brasileira de Biociências. 2009;7(4):463-72.

Baker NR. Chlorophyll Fluorescence: a probe of photosynthesis in vivo. Annual Review of Plant Biology. 2008;59(1):89-113. doi: 10.1146/annurev. arplant.59.032607.092759

Banks JM. Continuous excitation chlorophyll fluorescence parameters: a review for practitioners. Tree Physiology. 2017;37(8):1128-36. doi: 10.1093/ treephys/tpx059

Bellote AFJ, Neves EJM. Calagem e adubação em espécies florestais plantadas na propriedade rural. Circular técnica. 2001;54:1-6.

Berghetti ÁLP, Araujo MM, Bovolini MP, Tonetto TS, Muniz MFB. Morfologia de Plântulas e Controle de Patógenos em Sementes de Cordia trichotoma. Floresta e Ambiente. 2015;22(1):99-106. doi: 10.1590/21798087.076614

Berghetti ÁLP, Maristela MA, Tonetto TS, Aimi SC, Navroski MC, Turchetto F, et al. Growth of Cordia trichotoma seedlings in different sizes of recipients and doses of fertilizer. African Journal of Agricultural Research. 2016;11(28):2450-5. doi: https://doi. org/10.5897/AJAR2016.10883

Bortoluzzi EC, Pérez CAS, Ardisson JD, Tiecher T, Caner L. Occurrence of iron and aluminum sesquioxides and their implications for the $\mathrm{P}$ sorption in subtropical soils. Applied Clay Science. 2015;104:196204. doi: https://doi.org/10.1016/j.clay.2014.11.032

Brunetto G, Nava G, Ambrosini VG, Comin JJ, Kaminski J. The pear tree response to phosphorus and potassium fertilization. Revista Brasileira de Fruticultura. 2015;37(2):507-16. doi: 10.1590/0100- 
Cadorin DA, Malavasi UC, Coutinho PWR, Dranski JAL, Malavasi MM. Metil jasmonato e flexões caulinares na rustificação e crescimento inicial de mudas de Cordia trichotoma. Cerne. 2015;21(4):65764. doi: 10.1590/01047760201521042029

Coradin L, Siminski A, Reis A, editores. Espécies nativas da flora brasileira de valor econômico atual ou potencial: plantas para o futuro Região Sul. Brasília DF: MMA; 2011.

Crous KY, Ósvaldsson A, Ellsworth DS. Is phosphorus limiting in a mature Eucalyptus woodland?: phosphorus fertilisation stimulates stem growth. Plant and Soil. 2015;391(1-2):293-305. doi:10.1007/s11104-0152426-4

Ditzler KS, Monger HC (eds.). Soil Survey Manual. USDA Handbook 18. Soil Science. 2017;72(6):483. doi: 10.1097/00010694-195112000-00022

Elanchezhian R, Krishnapriya V, Pandey R, Rao AS, Abrol YP. Physiological and molecular approaches for improving phosphorus uptake efficiency of crops. Current Science. 2015;108(7):1271-79.

Fageria NK, Slaton NA, Baligar VC. Nutrient Management for Improving Lowland Rice Productivity and Sustainability. Advances in Agronomy. 2003;80:63-152. doi: https://doi.org/10.1016/S00652113(03)80003-2

Ferreira DF. Sisvar: a guide for its Bootstrap procedures in multiple comparisons. Ciência e Agrotecnologia. 2014;38(2):109-12. doi:10.1590/ S1413-70542014000200001

Fink JR, Inda AV, Bavaresco J, Barrón V, Torrent J, Bayer C. Adsorption and desorption of phosphorus in subtropical soils as affected by management system and mineralogy. Soil and Tillage Research. 2016;155:62-8. doi: https://doi.org/10.1016/j.still.2015.07.017

Gonçalves JLM, Stape JL, Laclau J-P, Bouillet J-P, Ranger J. Assessing the effects of early silvicultural management on long-term site productivity of fastgrowing eucalypt plantations: The Brazilian experience. Southern Forests. 2008a;70(2):105-18. doi: 10.2989/
Gonçalves JLM, Wichert MCP, Gava JL, Masetto AV, Arthur Junior JC, Serrano MIP, et al. Soil fertility and growth of Eucalyptus grandis in Brazil under different residue management practices. Southern Hemisphere Forestry Journal. 2008b;69(2):95-102. doi: 10.2989/ SHFJ.2007.69.2.4.289

Hidaka A, Kitayama K. Relationship between photosynthetic phosphorus-use efficiency and foliar phosphorus fractions in tropical tree species. Ecology and evolution. 2013;3(15):4872-80. doi: 10.1002 / ece 3.861

Hiscox JD, Israelstam GF. A method for the extraction of chlorophyll from leaf tissue without maceration. Canadian Journal of Botany. 1979;57(12):1332-34. doi: https://doi.org/10.1139/b79-163

Jiang H-X, Tang N, Zheng J-G, Li Y, Chen L-S. Phosphorus alleviates aluminum-induced inhibition of growth and photosynthesis in Citrus grandis seedlings. Physiologia Plantarum. 2009;137(3):298-311. doi: 10.1111/j.1399-3054.2009.01288.x

Lambers H, Finnegan PM, Laliberté E, Pearse SJ, Ryan MH, Shane MW, et al. Phosphorus Nutrition of Proteaceae in Severely Phosphorus-Impoverished Soils: are there lessons to be learned for future crops?. Plant Physiology. 2011;156(3):1058-66. doi: https://doi. org/10.1104/pp.111.174318

Lichtenthaler HK. Chlorophylls and carotenoids: Pigments of photosynthetic biomembranes. Methods in Enzymology. 1987;148:350-82. doi: http://dx.doi. org/10.1016/0076-6879(87)48036-1

Magalhães CAS, Morales MM, Rezende FA de, Langer J. Eficiência de fertilizantes organominerais fosfatados em mudas de eucalipto. Scientia Agraria. 2017;18(4):80-85. doi: 10.5380/rsa.v18i4.52247

Marschner H. Marschner's Mineral Nutrition of Higher Plants. 3 rd Ed. Petra Marschner; 2012. 651 p.

Melo EASC, Gonçalves JLM, Rocha JHT, Hakamada RE, Bazani JH, Wenzel AVA, et al. Responses of clonal eucalypt plantations to N, P and $\mathrm{K}$ fertilizer application in different edaphoclimatic conditions. Forests.

\section{Revista Árvore 2020;44:e4404}


2016;7(1):1-15. doi: https://doi.org/10.3390/f7010002

Noack SR, McLaughlin MJ, Smernik RJ, McBeath TM, Armstrong RD. Phosphorus speciation in mature wheat and canola plants as affected by phosphorus supply. Plant and Soil. 2014;378(1-2):125-37. doi: https://doi. org/10.1007/s11104-013-2015-3

Piccin R, Couto R da R, Bellinaso RJS, Gatiboni LC, Conti L De, Rodrigues LAT, et al. Phosphorus forms in leaves and their relationships with must composition and yield in grapevines. Pesquisa Agropecuária Brasileira. 2017a;52(5):319-27. doi: http://dx.doi. org/10.1590/s0100-204x2017000500005

Piccin R, Kaminski J, Ceretta CA, Tiecher T, Gatiboni LC, Bellinaso RJS, et al. Distribution and redistribution of phosphorus forms in grapevines. Scientia Horticulturae. 2017b;218:125-31. doi: https://doi. org/10.1016/j.scienta.2017.02.023

Rossi E, Sartoretto LM. Caracterização de três espécies florestais de importância econômica. Unoesc \& Ciência. 2014;5(2):145-52.

Schansker G, Tóth SZ, Holzwarth AR, Garab G. Chlorophyll a fluorescence: beyond the limits of the Q(A) model. Photosynthesis Research. 2014;120(12):43-58. doi: 10.1007/s11120-013-9806-5

Souza TC, Magalhães PC, Castro EM, Albuquerque PEP, Marabesi MA. The influence of ABA on water relation, photosynthesis parameters, and chlorophyll fluorescence under drought conditions in two maize hybrids with contrasting drought resistance. Acta Physiologiae Plantarum. 2013;35(2):515-27. doi: 10.1007/s11738-012-1093-9

Stirbet A, Govindjee. On the relation between the Kautsky effect (chlorophyll $\alpha$ fluorescence induction) and Photosystem II: basics and applications of the OJIP fluorescence transient. Journal of Photochemistry and Photobiology B: Biology. 2011;104(1-2):236-57. doi: https://doi.org/10.1016/j.jphotobiol.2010.12.010

Taiz L, Zeiger E. Plant Physiology. 5th ed. Porto Alegre: Artmed; 2013.

Tedesco MJ, Gianello C, Bissani CA, Bohnen H,
Volkweiss SJ. Análise de solo, plantas e outros materiais. 2.ed. rev. e ampl. Porto Alegre: Universidade Federal do Rio Grande do Sul; 1995.

Thomas DS, Montagu KD, Conroy JP. Why does phosphorus limitation increase wood density in Eucalyptus grandis seedlings? Tree physiology. 2006;26(1):35-42. doi: 10.1093 / treephys / 26.1.35

Tiecher TL, Tiecher T, Ceretta CA, Ferreira PAA, Nicoloso FT, Soriani HH, et al. Physiological and nutritional status of black oat (Avena strigosa Schreb.) grown in soil with interaction of high doses of copper and zinc. Plant Physiology and Biochemistry. 2016;106:253-63. doi: https://doi.org/10.1016/j. plaphy.2016.05.015

Tng DYP, Janos DP, Jordan GJ, Weber E, Bowman DMJS. Phosphorus limits Eucalyptus grandis seedling growth in an unburnt rain forest soil. Frontiers in Plant Science. 2014;5:527. doi: 10.3389/fpls.2014.00527

Turchetto F, Araujo MM, Tabaldi LA, Griebeler AM, Rorato DG, Aimi SC, et al. Can transplantation of forest seedlings be a strategy to enrich seedling production in plant nurseries?. Forest Ecology and Management. 2016;375:96-104. doi: http://dx.doi. org/10.1016/j.foreco.2016.05.029

Veneklaas EJ, Lambers H, Bragg J, Finnegan PM, Lovelock CE, Plaxton WC, et al. Opportunities for improving phosphurus-use efficiency in crop plants. New Phytologist. 2012;195(2):306-20. doi: https://doi. org/10.1111/j.1469-8137.2012.04190.x

Warren CR. How does P affect photosynthesis and metabolite profiles of Eucalyptus globulus?. Tree Physiology. 2011;31(7):727-39. doi: 10.1093/treephys/ tpr064

Wu P, Ma X, Tigabu M, Wang C, Liu A, Odén PC. Root morphological plasticity and biomass production of two Chinese fir clones with high phosphorus efficiency under low phosphorus stress. Canadian Journal of Forest Research. 2011;41(2):228-34. doi: 10.1139/ X10-198

Yang Z-K, Zheng J-W, Niu Y-F, Yang W-D, Liu J-S, Li H-Y. Systems-level analysis of the metabolic responses of the diatom Phaeodactylum tricornutum 
to phosphorus stress. Environmental microbiology. 2014;16(6):1793-807. doi: 10.1111 / 1462-2920.12411.

Yao Y, Sun H, Xu F, Zhang X, Liu S. Comparative proteome analysis of metabolic changes by low phosphorus stress in two Brassica napus genotypes. Planta. 2011;233(3):523-37. doi: 10.1007 / s00425010-1311-x

Zambrosi FCB, Mattos Junior D, Boaretto RM, Quaggio JA, Muraoka T, Syvertsen JP. Contribution of phosphorus (32P) absorption and remobilization for citrus growth. Plant and Soil. 2012a;355(1-2):353-62. doi: 10.1007/s11104-011-1107-1

Zambrosi FCB, Mattos Juniorr D, Furlani PR, Quaggio JA, Boaretto RM. Eficiência de absorção e utilização de fósforo em porta-enxertos cítricos. Revista Brasileira de Ciência do Solo. 2012b;36(2):485-96. doi: 10.1590/ S0100-06832012000200018

Zhou Z, Liu S, Liang K, Ma H, Huang G. Growth and mineral nutrient analysis of teak (Tectona grandis) grown on acidic soils in south China. Journal of Forestry Research. 2017;28(3):503-11. doi: 10.1007/ s11676-016-0324-0 